\title{
EFFECT OF HEAT STRESS ON THE PHYSIOLOGICAL PROCESSES OF WHEAT
}

\author{
K. BALLA, I. KARSAI, SZ. BENCZE, T. KISS and O. VEISZ \\ AGRICULTURAL INSTITUTE, CENTRE FOR AGRICULTURAL RESEARCH, HUNGARIAN \\ ACADEMY OF SCIENCES, MARTONVÁSÁR, HUNGARY
}

Received: ; accepted:

Stress tolerance is associated with the activation of antioxidant compounds and enzyme systems that are capable of neutralising the reactive oxygen species (ROS) continually produced in response to stress. The present experiment was designed to compare the heat tolerance of four winter wheat varieties in the shooting and grain-filling stages by investigating changes detected in antioxidant enzyme activity and yield components in response to heat stress.

Heat treatment was found to cause a significant rise in the activity of the glutathioneS-transferase and catalase enzymes, while there was usually a less intense decline in the activity of guaiacol peroxidase.

An analysis of yield data revealed that heat stress had a more pronounced effect during grain filling in this experiment than at the beginning of shooting, as shown by the greater reduction in thousand-kernel weight and yield.

Key words: shooting stage, grain-filling stage, high temperature stress, antioxidant enzyme activity

\section{Introduction}

Plant physiological processes are differentially affected by various environmental stresses, which may lead to the accumulation of reaction oxygen species (ROS), causing lipid peroxidation and consequently membrane injury, protein degradation, enzyme inactivation, pigment bleaching and the disruption of DNA strands (Imlay and Linn, 1988; Baisak et al., 1994; Sairam et al., 2000; Stepien and Klobus, 2005; Almeselmani et al., 2006).

The sources of ROS include photosynthetic electron transport (photosystems I and II) (Asada, 1999) and respiratory electron transport (Dat et al., 2000), both of which produce superoxide, while the excitation of chlorophyll molecules may lead to the formation of singlet oxygen. Even normal plant metabolism can thus generate considerable amounts of ROS. 
However, reactive oxygen species are also known to be signal molecules, playing an important role in cellular signal systems that, directly or indirectly, may induce a whole set of genes (Desikan et al., 2001; Apel and Hirt, 2004). They are also able to directly activate redox sensors, such as the transmembrane histidine kinases in bacteria and yeast (Singh, 2000; Quinn et al., 2002).

The cells and subcellular systems of plants are protected from the cytotoxic effects of ROS by antioxidant enzymes, such as ascorbate peroxidase, glutathione reductase and catalase, and by metabolites, such as glutathione, ascorbic acid and carotenoids.

Under normal conditions, the generation and scavenging of ROS is kept in balance, so ROS are not accumulated. If this equilibrium is disturbed by stress, however, ROS may accumulate due to the reduced activity of antioxidant enzymes (Luo et al., 2008). An increased level of intra- or intercellular ROS can be observed under heat stress conditions in various developmental stages (Sairam et al., 2000; Almeselmani et al., 2006; Luo et al., 2008).

The main aim of the present work was thus to determine the effect of the increasing occurrence of high temperatures during the shooting and grain-filling stages of development on the antioxidant enzyme activity of winter wheat.

\section{Materials and Methods}

\section{Plant material}

The heat tolerance of four winter wheat varieties (Fatima 2, Mv Mambó, Bánkúti 1201, GK Öthalom) was compared in two developmental stages, shooting and grain filling. The medium early variety Fatima 2 has excellent yield potential and good milling and bread-making quality. The early maturing Mv Mambó can be characterised as a high-yielding, good quality bread wheat with excellent adaptability and good drought tolerance. Bánkúti 1201 is an old Hungarian wheat variety with average or slightly better yield potential, hard endosperm structure and good rheological properties. It also has satisfactory climatic resistance and extremely good drought tolerance. GK Öthalom is an early maturing, high-yielding winter wheat with awnless spikes and high quality.

\section{Experimental design}

After 42 days of vernalisation at low light intensity, with short-day illumination at $4^{\circ} \mathrm{C}$, the seedlings were planted four to a pot in a 3:2:1 mixture of garden soil, compost and sand in round pots with a volume of $2800 \mathrm{~cm}^{3}$. The pots were placed randomly in phytotron growth chambers and were watered daily with tap water, supplemented with Volldünger nutrient solution twice a week until the beginning of heading. The temperature in the chambers changed weekly according to the spring/summer climatic programme (T2NY2) designed for wheat (Tischner et al., 1997).

The experiment included three treatments: control (C), heat stress at shooting (SH) and heat stress at grain filling (GF). The SH treatment was applied during the $8^{\text {th }}$ week after planting, at the end of tillering and the beginning of shooting (Zadoks 32) and the GF treatment 12 days after the heading date characteristic of the variety (Zadoks 75, Tottman and Makepeace, 1979). The stress treatment was continued for 15 days in a G-30 growth cabinet. Each variety was represented by 15 pots, five for each treatment.

For young plants in the shooting stage, the day/night temperature in the PGV-36 plant growth chambers used for the control treatment was $17 / 13^{\circ} \mathrm{C}$, while the heat stress treatment was carried out at $30 / 20^{\circ} \mathrm{C}$ in a G-30 growth cabinet, with a light intensity of $320 \mu \mathrm{mol} \mathrm{m}^{-2} \mathrm{~s}^{-1}$ and a 
day length of $12 \mathrm{~h}$. For adult plants in the grain-filling stage the temperature in the control treatment was adjusted to $24 / 20^{\circ} \mathrm{C}$, while heat stress was carried out at $35 / 20^{\circ} \mathrm{C}$ with a light intensity of $350 \mu \mathrm{mol} \mathrm{m} \mathrm{m}^{-2} \mathrm{~s}^{-1}$ and a day length of $14 \mathrm{~h}$. The high temperatures were programmed for $8 \mathrm{~h}$ each day (Tischner et al., 1997).

The data were statistically evaluated using two-way analysis of variance (ANOVA) with replications (Láng et al., 2001).

Measurement of antioxidant enzyme activity

Leaf samples of all four varieties were collected from each treatment in five replications on the $1^{\text {st }}$ and $7^{\text {th }}$ days of heat stress. $0.5 \mathrm{~g}$ leaf samples were cut from the middle regions of the flag leaves and kept at $-85^{\circ} \mathrm{C}$ until they were analyzed for antioxidant enzyme activities. Leaf extracts were homogenized with sand in $2.5 \mathrm{ml}$ ice-cold $0.5 \mathrm{M}$ Tris-buffer ( $\mathrm{pH} 7.4$ ). The enzyme activity was recorded photometrically (Shimadzu UV-VIS 160A) at room temperature. Three antioxidant enzymes were investigated: glutathione-S-transferase (GSH-S-Tr), guaiacol peroxidase (GPx) and catalase (CAT).

The activity of GSH-S-Tr was recorded as the change in absorbance at $340 \mathrm{~nm}$ in a reaction mixture containing $72.7 \mathrm{mM}$ Na-phosphate buffer $(\mathrm{pH} 6.5), 3.6 \mathrm{mM}$ reduced glutathione (GSH), $1 \mathrm{mM}$ 1-chloro-2,4-dinitrobenzene (CDNB) and $100 \mu \mathrm{l}$ plant extract (Mannervik and Guthenberg, 1981).

GPx activity was determined as described by Ádám et al. (1995). Changes in absorbance due to the oxidation of guaiacol were recorded spectrophotometrically at $470 \mathrm{~nm}$. The reaction mixture consisted of $1 \mathrm{ml} 1 \mathrm{mM}$ guaiacol and $50 \mu \mathrm{l}$ plant sample in $0.1 \mathrm{M} \mathrm{Na}$-acetate buffer $(\mathrm{pH}$ 5.5), and the reaction was initiated by the addition of $300 \mu 11.3 \mathrm{mM} \mathrm{H}_{2} \mathrm{O}_{2}$ solution.

In the case of CAT the reaction mixture contained $0.5 \mathrm{mM}$ Tris buffer (pH 7.4), $10 \mathrm{mM}$ $\mathrm{H}_{2} \mathrm{O}_{2}$ and $50 \mu \mathrm{l}$ plant sample in a total volume of $3 \mathrm{ml}$. The CAT activity of the extract was measured spectrophotometrically by monitoring the decrease in absorbance at $240 \mathrm{~nm}$ (Janda et al., 2008).

\section{Results}

\section{Changes in heading date and number of tiller in response to heat stress}

Exposure of plants to high temperatures in various stages of development may have different effects on the length of the vegetation period and on yield parameters. The number of days from planting to heading was recorded for wheat varieties subjected to heat stress at the beginning of shooting (Fig. 1). The heading date of plants exposed to $30^{\circ} \mathrm{C}$ for 15 days was compared to that of plants in the control treatment. For all four varieties, heat-stressed plants were found to head earlier than their non-stressed counterparts.

When heat stress was carried out at shooting, in the $8^{\text {th }}$ week, the number of tillers was recorded for each wheat variety before and after the heat treatment (Fig. 2). High temperature at the beginning of shooting was found to cause the tillers to wither in all the varieties. This was most severe for GK Öthalom, while Fatima 2 was the least affected.

\section{Changes in antioxidant enzyme activity in response to heat stress}

Glutathione-S-transferase (GSH-S-Tr) is an important antioxidant enzyme in the defence against oxidative stress. In the shooting stage, the activity of this enzyme was found to increase in control plants between the $1^{\text {st }}$ and the $7^{\text {th }}$ day 
(Fig. 3). In response to heat stress only one variety exhibited an increase in enzyme activity on the first day of heat treatment, while the increase was significant for all the varieties by the $7^{\text {th }}$ day. In the grain-filling stage the level of GSH-S-Tr activity on the $1^{\text {st }}$ day of treatment was much higher than in the shooting stage even in the control, while in the heat treatment it was around three times higher than in the young plants. By the $7^{\text {th }}$ day of treatment, however, there was a decrease in enzyme activity both in the control and heat-stressed plants. For all four varieties the increase in GSH-S-Tr activity in response to heat stress was significant both on the $1^{\text {st }}$ and the $7^{\text {th }}$ day compared with the control.

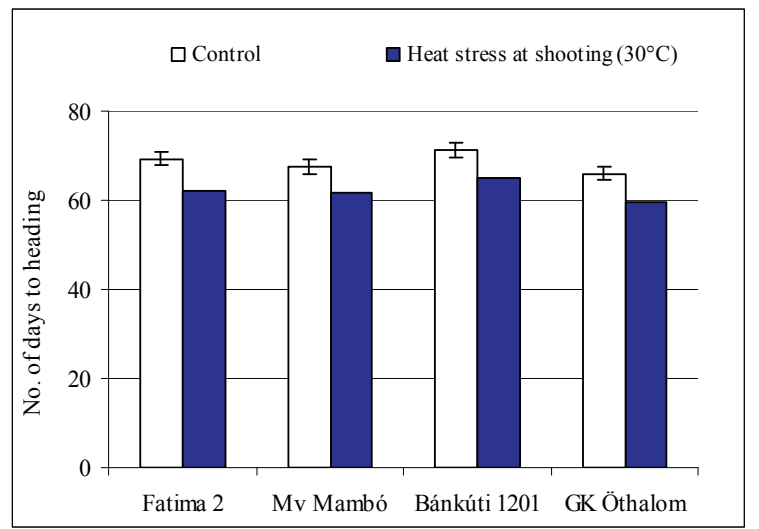

Fig. 1. Changes in the number of days from planting to heading in response to heat stress in the shooting stage (Bars indicate significant differences at the $\mathrm{P} \leq 0.05$ level of probability)

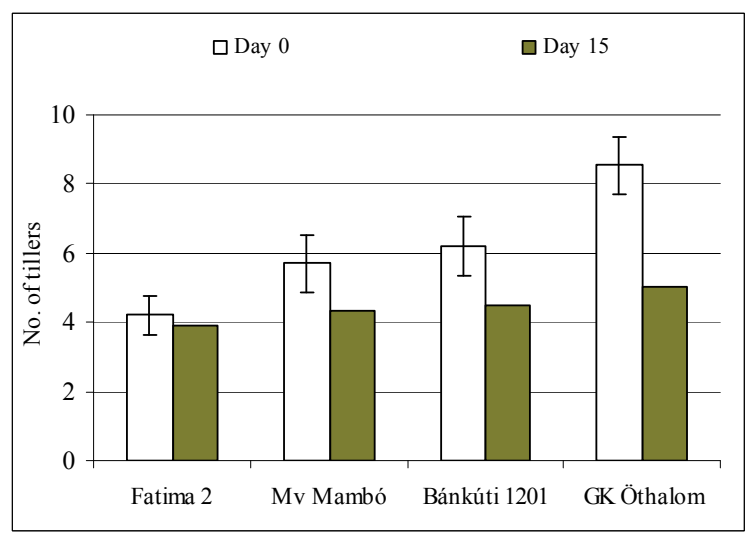

Fig. 2. Changes in the number of tillers of winter wheat varieties exposed to $30^{\circ} \mathrm{C}$ heat stress in the shooting stage Day 0: before heat stress; Day 15: after heat stress (Bars indicate significant differences at the $\mathrm{P} \leq 0.05$ level of probability) 

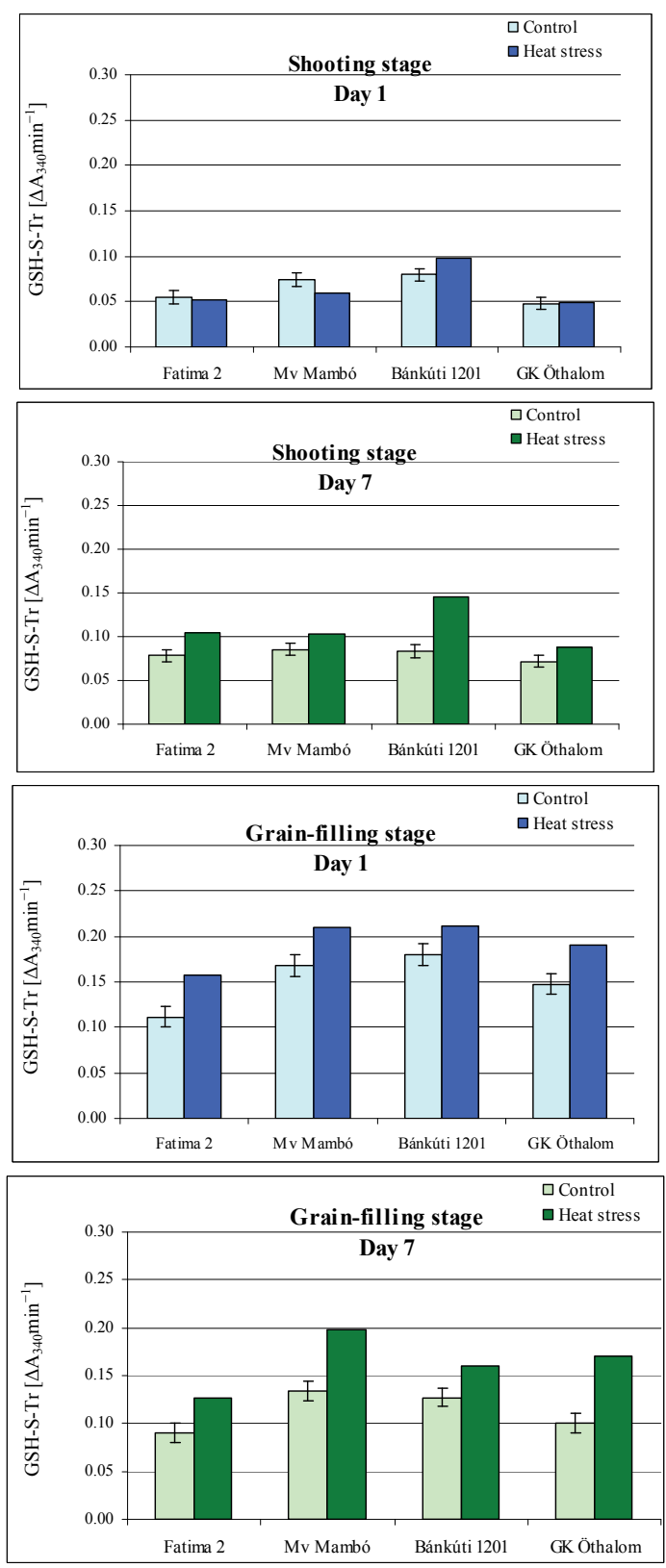

Fig. 3. Changes in the activity of glutathione-S-transferase (GSH-S-Tr), expressed as the absorbance of enzyme extracts prepared from control and heat-stressed samples of four winter wheat varieties on the $1^{\text {st }}$ and $7^{\text {th }}$ days of treatment during the shooting and grain-filling stages (Bars indicate significant differences at the $\mathrm{P} \leq 0.05$ level of probability) 
Considerable differences were noted in the activity of the guaiacol peroxidase (GPx) enzyme between the two heat stress treatments (Fig. 4). As observed for all the enzymes, the activity of GPx gave a much greater response to stress during grain filling than at the shooting stage. In the control treatment the GPx activity increased considerably between the $1^{\text {st }}$ and $7^{\text {th }}$ days in the shooting stage, while little difference was recorded between the beginning and end of the treatment period at the grain-filling stage. The most pronounced difference was observed for the response to heat stress in the shooting stage. While only one variety responded with a significant decrease in GPx activity on the first day, this was true of all the varieties on the $7^{\text {th }}$ day of treatment. There also tended to be a decline in enzyme activity in response to heat treatment in the grain-filling stage, but in most cases this was not significant at the $\mathrm{P} \leq 0.05$ level.

Catalase (CAT) is the second most important antioxidant enzyme and is responsible for the neutralisation of $\mathrm{H}_{2} \mathrm{O}_{2}$. Even in the control plants there was a rise in enzyme activity between days 1 and 7, but almost all the wheat varieties responded to high temperature stress with a significant increase in the catalase activity on the first day in both the shooting and grain-filling stages (Fig. 5). By the $7^{\text {th }}$ day there tended to be a slight reduction in activity, but it remained significantly higher in two of the four varieties at shooting and in three at grain filling. In the grain-filling stage GK Öthalom had exceptionally high catalase activity on both the $1^{\text {st }}$ and $7^{\text {th }}$ days compared with the other varieties.

\section{Changes in yield parameters to heat stress}

Considerable differences were detected between the treatments in the changes in yield parameters due to heat stress (Table 1), though it should be noted that the experimental conditions (e.g. taking samples from the plants) may have had a slight influence on these parameters. Substantial differences were recorded for the harvest index, which responded more sensitively to heat stress during grain filling, while this parameter was less affected when the plants were stressed in the late tillering/early shooting stage. Only the harvest index of $\mathrm{Mv}$ Mambó was significantly reduced by high temperature at the beginning of shooting.

Heat stress had little influence on the grain number, though Mv Mambó was again the exception, responding with a significant decline to stress in both phenophases. While a temperature of $30^{\circ} \mathrm{C}$ at shooting did not cause a significant change in the thousand-kernel weight, the $35^{\circ} \mathrm{C}$ treatment at grain filling resulted in a substantial decline in this parameter. The effect of high temperature on the grain yield also proved to be most severe in the grain-filling stage (Table 1). Fatima 2, Mv Mambó and Bánkúti 1201 responded with a significant yield loss to heat stress during grain filling, while treatment in the shooting stage only caused a reduction in yield in the case of Mv Mambó. 

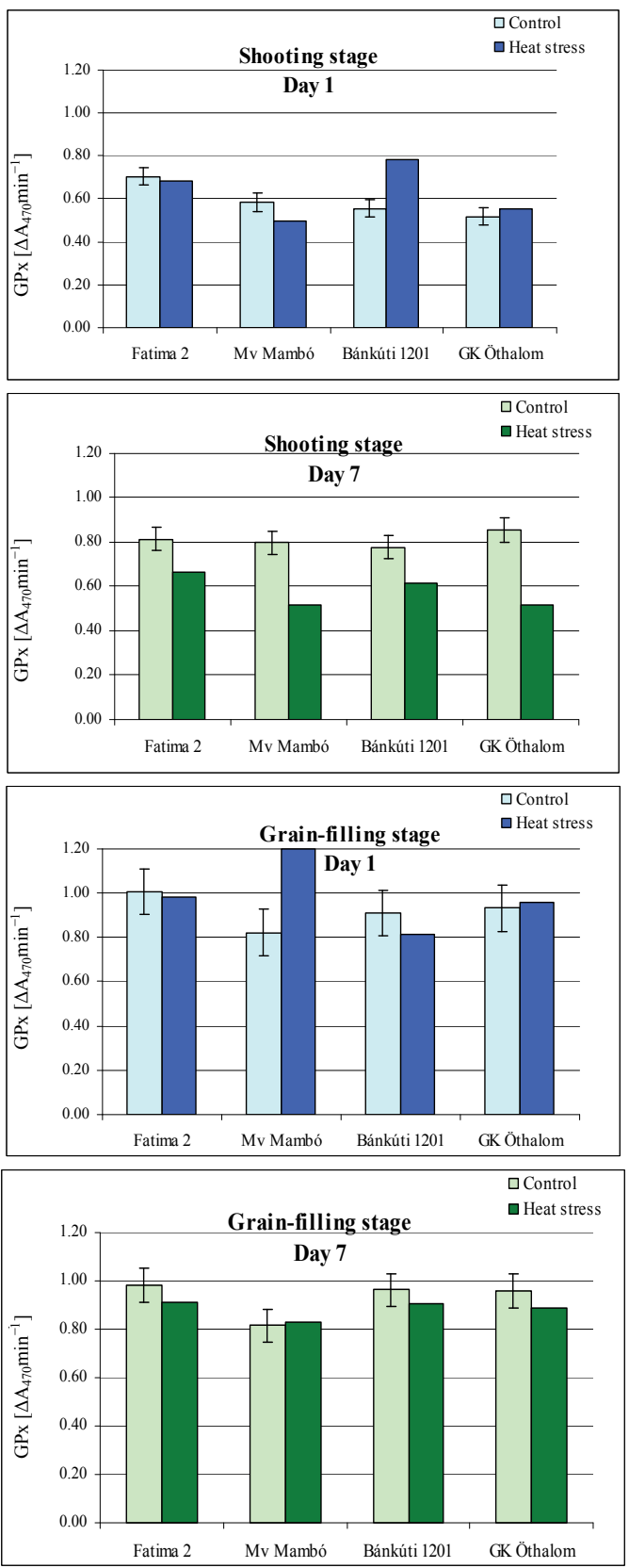

Fig. 4. Changes in the activity of guaiacol peroxidase (GPx), expressed as the absorbance of enzyme extracts prepared from control and heat-stressed samples of four winter wheat varieties on the $1^{\text {st }}$ and $7^{\text {th }}$ days of treatment during the shooting and grain-filling stages (Bars indicate significant differences at the $\mathrm{P} \leq 0.05$ level of probability) 

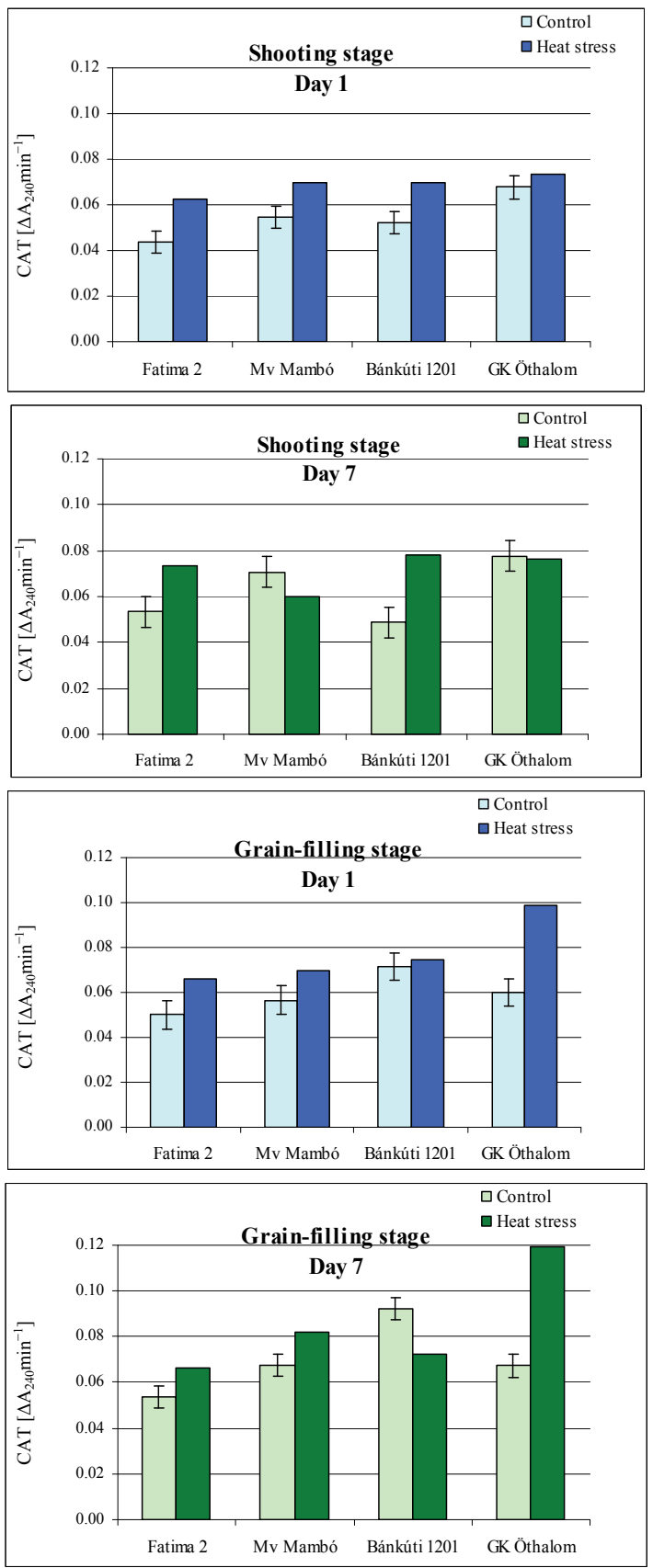

Fig. 5. Changes in the activity of catalase (CAT), expressed as the absorbance of enzyme extracts prepared from control and heat-stressed samples of four winter wheat varieties on the $1^{\text {st }}$ and $7^{\text {th }}$ days of treatment during the shooting and grain-filling stages

(Bars indicate significant differences at the $\mathrm{P} \leq 0.05$ level of probability) 
Table 1

Changes in yield parameters in response to heat stress at shooting $(\mathrm{SH})$ and grain filling (GF)

\begin{tabular}{ccccc}
\hline Harvest Index & Control & Heat stress (SH) & Heat stress (GF) & LSD $_{5 \%}$ \\
\hline Fatima 2 & 34.47 & 34.25 & $26.00^{*}$ & 2.98 \\
Mv Mambó & 40.46 & $30.89^{*}$ & $31.86^{*}$ & 2.98 \\
Bánkúti 1201 & 36.23 & 37.92 & $26.71^{*}$ & 2.98 \\
GK Öthalom & 33.61 & 35.73 & 34.64 & 2.98 \\
\hline Grain Number & Control & Heat stress (SH) & Heat stress (GF) & LSD $_{5 \%}$ \\
\hline Fatima 2 & 73.05 & 81.70 & 84.80 & 17.09 \\
Mv Mambó & 94.60 & $52.20^{*}$ & $77.20^{*}$ & 17.09 \\
Bánkúti 1201 & 75.84 & 72.15 & 89.04 & 17.09 \\
GK Öthalom & 85.45 & 93.75 & 90.80 & 17.09 \\
\hline & Control & Heat stress (SH) & Heat stress (GF) & LSD $_{5 \%}$ \\
\hline TKW & 25.77 & 26.01 & $16.18^{*}$ & 2.80 \\
\hline Fatima 2 & 30.91 & 30.08 & $22.78^{*}$ & 2.80 \\
Mv Mambó & 35.47 & 37.31 & $23.89^{*}$ & 2.80 \\
Bánkúti 1201 & 26.07 & 27.03 & 25.34 & 2.80 \\
GK Öthalom & Control & Heat stress (SH) & Heat stress (GF) & LSD $_{5 \%}$ \\
\hline Grain Yield & 1.86 & 2.12 & $1.31^{*}$ & 0.41 \\
& Fatima 2 & $1.52^{*}$ & $1.77^{*}$ & 0.41 \\
Mv Mambó & 2.91 & 2.63 & $2.14^{*}$ & 0.41 \\
Bánkúti 1201 & 2.67 & 2.54 & 2.26 & 0.41 \\
GK Öthalom & 2.25 & & &
\end{tabular}

TKW: Thousand-kernel weight; ${ }^{*}$ Differences significant at the $\mathrm{P} \leq 0.05$ level

\section{Discussion}

The application of high temperature $\left(30^{\circ} \mathrm{C}\right)$ at the end of tillering/beginning of shooting significantly shortened the time required until heading in all the varieties tested, compared with the control plants, partially confirming the results published by Rahman et al. (2009), who noted an acceleration in development, flowering and ripening in response to higher temperature $\left(30 / 25^{\circ} \mathrm{C}\right)$, as proved by a significant reduction in the days to booting, heading, flowering and maturity.

The analysis of antioxidant enzyme activity revealed an increase in the activity of all the enzymes tested by the $7^{\text {th }}$ day in control plants during the shooting stage, probably due to the intensive growth in early stages of development. Janda et al. (2007) also observed that numerous factors may be responsible for modifications in enzyme activity. Under normal conditions, for example, aging may cause a reduction in CAT and an increase in the activity of the peroxidases. Cold hardening was also found to reduce the activity of catalase (Janda et al., 2003). In the present work, the least pronounced changes were recorded for GPx, the activity of which tended to decrease. This could indicate that this enzyme was degraded to a great extent by heat stress. By contrast, GSH-S-Tr and CAT responded to heat stress with a significant increase in 
activity. Many authors have reported that the enhanced activity of these enzymes could contribute to the development of tolerance of various stress factors (Foyer et al., 1991; Sairam et al., 2002; Almeselmani, 2006).

GPx was the only antioxidant enzyme whose activity declined by the $7^{\text {th }}$ day of heat stress in the shooting stage. Dash and Mohanty (2002) demonstrated that even enzymes that remained active when seedlings were treated at nonlethal temperatures of $30^{\circ} \mathrm{C}$ or $35^{\circ} \mathrm{C}$ became inactive when the temperature was increased to $40^{\circ} \mathrm{C}$.

It was found by Sabeva and Nedeva (2008) that catalase, an antioxidant enzyme involved in the decomposition of $\mathrm{H}_{2} \mathrm{O}_{2}$, was the most sensitive to the applied stress factors. A decrease in CAT activity in the leaves and roots may result in greater lipid peroxidation, indicated by a rise in the malondialdehyde (MDA) content. This was confirmed by the present results, since heat stress both at shooting and in the grain-filling stage resulted in a substantial increase in the CAT activity, in order to provide protection against the ROS produced in response to high temperature and to achieve better heat tolerance.

GSH-S-Tr is another important part of the plant antioxidant system. The intensive rise in the activity of this enzyme in response to heat stress both at shooting and grain filling was an indication of the increased presence in the cells of ROS, which are detoxified to a great extent by GSH-S-Tr. Particularly high levels of enzyme activity were recorded on both the $1^{\text {st }}$ and $7^{\text {th }}$ days when treatment was carried out in the grain-filling stage.

Among the varieties tested, Bánkúti 1201 exhibited a significant rise in the activity of all three antioxidant enzymes when high temperature was applied at shooting, but in the grain-filling stage the increase in enzyme activity was less pronounced than in Mv Mambó, Fatima 2 and GK Öthalom.

An analysis of the yield parameters revealed that heat stress had less influence when applied in the tillering/shooting stage than at grain filling. High temperature had the most pronounced effect on the thousand-kernel weight and the grain yield. The harvest index only declined significantly in response to heat stress at the beginning of shooting in the case of Mv Mambó. In both phenophases a substantial reduction in the grain number was again only recorded for this variety, which also exhibited the greatest reduction in yield after treatment in the shooting stage.

These results thus confirmed the more damaging effect of heat stress in the grain-filling stage, as also indicated by the more intense antioxidant enzyme activity recorded in the plants after high temperature treatment during this phenophase.

The research performed by Sairam et al. (2000) also indicated that the tolerance of individual wheat varieties appeared to be correlated with their antioxidant enzyme activity, though the various enzymes capable of counteracting oxidative stress did not exhibit a uniform rise in activity in the genotypes tested. 
The changes in the activity of antioxidant enzymes thus show that these enzymes play an important role in the neutralisation of the toxic compounds formed in plants in response to heat stress and in the development of heat tolerance, despite the fact that the antioxidant responses to heat stress differed for the varieties tested in different stages of development. The great variability in the stress responses reported in the literature for various antioxidant enzymes can probably be attributed to genotypic differences.

\section{Acknowledgements}

This project was funded from the DROPS Project (EU-FP7 No. 244374) and from grants Nos. TÁMOP-4.2.2/B-10/1-2010-0025 and TÁMOP-4.2.2.A-11/1KONV-2012-0064.

\section{References}

Ádám, A., Bestwick, C. S., Barna, B., Mansfield, J. W. (1995): Enzymes regulating the accumulation of active oxygen species during the hypersensitive reaction of bean to Pseudomonas syringae pv. phaseolicola. Planta, 197, 240-249.

Almeselmani, M., Deshmukh, P. S., Sairam, R. K., Kushwaha, S. R., Singh, T. P. (2006): Protective role of antioxidant enzymes under high temperature stress. Plant Sci., 171, 382388.

Apel, K., Hirt, H. (2004): Reactive oxygen species: metabolism, oxidative stress, and signal transduction. Annu. Rev. Plant Biol., 55, 373-399.

Asada, K. (1999): The water-water cycle in chloroplasts: scavenging of active oxygen and dissipation of excess photons. Annu. Rev. Plant Physiol. Plant Mol. Biol., 50, 601-639.

Baisak, R., Rana, D., Acharya, P. B. B., Kar, M. (1994): Alterations in the activities of active oxygen scavenging enzymes of wheat leaves subjected to water stress. Plant Cell Physiol., 35, 489-495.

Dash, S., Mohanty, N. (2002): Response of seedlings to heat-stress in cultivars of wheat: Growth temperature-dependent differential modulation of photosystem 1 and 2 activity, and foliar antioxidant defense capacity. J. Plant Physiol., 159, 49-59.

Dat, J., Vandenabeele, S., Vranova, E., Van Montagu, M., Inzé, D., Van Breusegem, F. (2000): Dual action of the active oxygen species during plant stress responses. Cell. Mol. Life Sci., 57, 779-795.

Desikan, R., Mackerness, S. A.-H., Hancock, J. T., Neill, S. J. (2001): Regulation of the Arabidopsis transcriptome by oxidative stress. Plant Physiol., 127, 159-172.

Foyer, H. C., Lelandais, M., Galap, C., Kunert, K. J. (1991): Effects of elevated cytosolic glutathione reductase activity on the cellular glutathione pool and photosynthesis in leaves under normal and stress conditions. Plant Physiol., 97, 863-872.

Imlay, J. A., Linn, S. (1988): DNA damage and oxygen radical toxicity. Science., 240, 1302-1309.

Janda, T., Cséplő, M., Németh, C., Vida, G., Pogány, M., Szalai, G. (2008): Combined effect of water stress and infection with the necrotrophic fungal pathogen Drechslera triticirepentis on growth and antioxidant activity in wheat. Cereal Res. Commun., 36, 53-64.

Janda, T., Szalai, G., Leskó, K., Yordanova, R., Apostol, S., Popova, L. P. (2007): Factors contributing to enhanced freezing tolerance in wheat during frost hardening in the light. Phytochemistry, 68, 1674-1682.

Janda, T., Szalai, G., Rios-Gonzalez, K., Veisz, O., Páldi, E. (2003): Comparative study of frost tolerance and antioxidant activity in cereals. Plant Sci., 164, 301-306.

Láng, L., Kuti, C., Bedő, Z. (2001): Computerized data management system for cereal breeding. Euphytica, 119, 235-240. 
Luo, Y., Li, W-M., Wang, W. (2008): Trehalose: Protector of antioxidant enzymes or reactive oxygen species scavenger under heat stress? Environ. Exp. Bot., 63, 378-384.

Mannervik, B., Guthenberg, C. (1981): Glutathione transferase (Human placenta). Method Enzymol., 77, 231-235.

Quinn, J., Findlay, V. J., Dawson, K., Millar, J. B., Jones, N. (2002): Distinct regulatory proteins control the graded transcriptional response to increasing $\mathrm{H}_{2} \mathrm{O}_{2}$ levels in fission yeast Schizosaccharomyces pombe. Mol. Biol. Cell, 13, 805-816.

Rahman, M. A., Chikushi, J., Yoshida, S., Karim, J. M. S. (2009): Growth and yield components of wheat genotypes exposed to high temperature stress under control environment. Bangladesh J. Agr. Res., 34, 361-372.

Sabeva, S., Nedeva, D. (2008): Antioxidant enzymes in germinating wheat seeds as affected by dehydration stress, ABA and hydrogen peroxide. Acta Agron. Hung., 56, 113-127.

Sairam, R. K., Rao, K. V., Srivastava, G. C. (2002): Differential response of wheat genotypes to long term salinity stress in relation to oxidative stress, antioxidant activity and osmolyte concentration. Plant Sci., 163, 1037-1046.

Sairam, R. K., Srivastava, G. C., Saxena, D. C. (2000): Increased antioxidant activity under elevated temperatures: a mechanism of heat stress tolerance in wheat genotypes. Biol. Plant., 43, 245-251.

Singh, K. K. (2000): The Saccharomyces cerevisiae SLN1P-SSK1P two-component system mediates response to oxidative stress and in an oxidant-specific fashion. Free Rad. Biol. Med., 29, 1043-1050.

Stepien, P., Klobus, G. (2005): Antioxidant defense in the leaves of C3 and C4 plants under salinity stress. Physiol. Plant., 125, 31-40.

Tischner, T., Rajkainé Végh, K., Köszegi, B. (1997): Effect of growth medium on the growth of cereals in the phytotron. Acta Agron. Hung., 45, 187-193.

Tottman, D. R., Makepeace, R. J. (1979): An explanation of the decimal code for the growth stages of cereals, with illustrations. Ann. Appl. Biol., 93, 221-234.

Corresponding author: K. Balla

Fax: 22/460-213

E-mail:balla.krisztina@agrar.mta.hu 